\title{
Power, the Hidden Factor in Development Cooperation. An Example of Community Forestry in Cameroon
}

\author{
Mbolo C. Yufanyi Movuh, Carsten Schusser \\ Forest and Nature Conservation Policy, Georg August University Goettingen, \\ Goettingen, Germany \\ Email: cyufani@gwdg.de
}

Received July $23^{\text {rd }}, 2012$; Revised August $26^{\text {th }}, 2012$; Accepted September $15^{\text {th }}, 2012$

\begin{abstract}
This paper is concomitant with our comparative study analysis of the interests and power of the stakeholders involved in Community Forestry (CF) in six countries. The study hypothesises that, "governance processes and outcomes in CF depend mostly on interests of the powerful external stakeholders". For this paper which is on CF in Cameroon, the study hypothesizes that, "Power is a hidden factor in Development cooperation". Based on political theories, the paper uses the "actor-centered power" (ACP) concept of the Community Forestry Working Group (CFWG) in Göttingen, Germany, the post-development theory and empirical findings, to back up the assertations made in the study through the analysis of thirteen different CFs in the South West region (SWR) of Cameroon. It analyzes the empirically applicable ACP concept, that consists of three elements: trust, incentives and coercion and at the same time connects these elements with the post-development theory. The elements were derived from the basic assumptions on power made by Max Weber in political sciences and Max Krott in forest policy. The study confirms the existence of powerful internal and external stakeholders that influence CF in Cameroon and aims to empower important but marginalised communities. It concludes that, $\mathrm{CF}$ as a development instrument to alleviate poverty and increase livelihood while sustainably managing the forest has actually not brought significant or meaningful development to the targeted sector of the society.
\end{abstract}

Keywords: Community Forestry; Devolution; Power; Development; Post-Development; Theory; Trust; Incentive; Coercion

\section{Introduction}

As community forestry (CF) is being recognized as a paradigm shift (La Viña, 1997; Rebugio, 1998; Devkota, 2010) of forest policy in the so-called developing countries, ${ }^{1}$ it is essential to understand the power processes and its distribution behind it. This makes it easier to understand the way power is wielded among stakeholders (Devkota, 2010: p. 6), hence, identifying the different interests and influence. Furthermore, many global funding agencies have bought into the idea of CF and feel that it is a far more ethical way of donating money for the protection of forest and at the same time fulfilling their development agenda. Millions of Euros are being invested in CF programs all over the world with very little success in their implementation, management and monitoring, not achieving the goals of biodiversity protection and increased human wellbeing as always proclaimed in discourse and rhetoric, in the name of Development. In Cameroon for instance, most of the community forests were established through projects implemented by NGOs and drawing on donor support (Mandondo, 2003: p. 17).

In implementing $\mathrm{CF}$, the forest condition (sustainable management) is often referred to as a precondition for positive social and economic outcomes. Nonetheless, in many cases, forests are devolved to local arenas after they have been severely

${ }^{1}$ This is regarded as a new forestry paradigm favouring a people-oriented approach generally termed "community forestry" or "participatory forestry," rather than the previous top-down forest policies of these countries. exploited and are in a degraded condition (Mandondo, 2003: p. 15), while states appear to have initiated the devolution concept to restore degraded forest lands by taking advantage of cheap and voluntary labour (Shackleton et al., 2002; Sarin et al., 2003; Colfer, 2005; Larson, 2005; Contreras, 2003; Edmunds \& Wollenberg, 2001; Thoms, 2006; Devkota, 2010). Furthermore, in the devolution of some usufruct and to a limited extend participation rights to local communities, institutional arrangements had not been followed by the establishment of more effective institutions (Poffenberger, 2006; Yufanyi Movuh \& Krott, 2011). Larson (2005) and Devkota (2010) mention that at times after locals have invested in the protection of these resources and improved their status, the state often re-appropriates these forest resources. For Larson and Ribot (2007: p. 3), forest policy and the implementation "- systematically exclude various groups from forest benefits-and often impoverish and maintain the poverty of these groups". Also, the concept of CF in Cameroon has been attributed to colonial heritage and postcolonial entanglement to the former colonial masters (Yufanyi Movuh \& Krott, 2011: p. 77), with power and interests of stakeholders being seen to influence outcomes of CF. With such critical findings, it is but adequate to question the concept of $\mathrm{CF}$ (as a pro community policy implementation instrument) and further examine the factors contributing to it not achieving its proclaimed objectives (Devkota, 2010: p. 2).

Most often than not, power comes in many forms and is concealed where it is strongest and therefore resists scientific analyses (Krott, 2005: p. 14). Consequently, CF analysis through 
the power spectrum require a logically and theoretically based concept of power based on social relationships. As an important phenomenon in social relation, power analysis is very necessary in forest policy as well as in other domains. By referring to the classic sociological definition of power by Max Weber (1947: p. 152), Krott (2005: p. 14) relates the issue in forest policy as, "those who utilize or protect forests are forced to subordinate their interests to politically determined programs in the face of conflict". This, he explains, results from "stakeholders and political players availing themselves of power" (Krott, 2005: p. 14; Devkota, 2010: p. 6), leading to criticism of development as a whole and the CF programs in particular. In criticizing the development theory as a whole ${ }^{2}$, I chose CF as a case study and show how power and the interest, characteristics and circumstances (Mayers, 2005) of the powerful stakeholders are exhibited in the era of post-development theory. This could be well ostracised in a situation where conservationism, sustainable and participatory forest management for economic benefits are notably tied with the politics of funding, conditioned upon the adoption and mainstreaming of such viewpoints in national policy arenas (Mandondo, 2003: p. 23). The study also sheds light on how and why countries with rich forests, especially African countries like Cameroon, are generally marginalized in international forestry think-tank, decision-making and trendsetting institutions ${ }^{3}$.

The main hypothesis of the interest and power analysis is that, "governance processes and outcomes in CF depend mostly on interests of the powerful external stakeholders". To test the hypothesis, a comparative research study was carried out on "Stakeholders" Interests and Power as Drivers of Community Forestry". The comparative research project is conducted in Albania, Cameroon, Germany, Indonesia, Namibia and Nepal, in three different continents. Pertaining to $\mathrm{CF}$ in Cameroon, the study hypothesizes that, "Power is a hidden factor in development assistance". It uses a simple concept of power suggested by the Community Forestry Working Group (CFWG), the post-development theory and empirical findings, to back up the assertations made in the study, and is strictly reduced to the basics of social interaction. This approach helps understanding the present $\mathrm{CF}$ model in Cameroon, by identifying the key actors or stakeholders in the system, and assessing their respective interests in, or influence on, that system (Mayers, 2005: p. 3).

\section{CF and its Rationale in Cameroon}

In the last 3 decades, $\mathrm{CF}^{4}$ has been hailed by researchers, policy makers, governments and Organisations alike (Brown et al., 2007: p. 136; Pulhin \& Dressler, 2009) as a successful contemporary paradigm and implementation mechanism for sustainable forest resources management, decentralization and devolution (Ezzine de Blas et al., 2009; Larson \& Ribot, 2004; World Bank, 2004; World Bank, 2005; WRI, 2005). Based on its theoretical decentralization and devolution characteristics, it has been promoted by international bi- and multilateral green

\footnotetext{
${ }^{2}$ Development theory is a combination of theories about how desirable change in the so-called third world societies can be best obtained, by following the examples of the development processes of the so-called first world societies. These theories are based on a variety of social scientific disciplines and approaches.

${ }^{3}$ ibid.

"We define "Community Forestry" as "forestry which directly involves local forest users in the common decision making and implementation of forestry activities" (CFWG in Göttingen).
}

Organizations, development agencies (Agrawal \& Redford, 2006) and western governments, becoming one of the most practiced participatory models ${ }^{5}$ of forest management as an alternative to previous models (Barry et al., 2003; Sikor, 2006: p. 339), promising and aiming at alleviating poverty of many forest dependent communities while at the same time sustainably managing their forest (Maryudi et al., 2011; Yufanyi Movuh \& Krott, 2011; Maryudi, 2011).

But the common reality across the globe and Cameroon in particular is that, the governance process of CF has not yet produced expected outcomes (Yufanyi Movuh \& Krott, 2011; MINEP, 2004; Devkota, 2010). While McDermott and Schreckenberg (2009: p. 158) have elaborated CF as the exercise by local people of power to influence decisions regarding management of forests, including the rules of access and the disposition of products; in Cameroon, the "power shift" rhetoric from the state to the local communities through CF opens a question of power sharing, when these management objectives would really be put into practice. In Cameroon since 1995, a new forest policy act was enacted (proclaimed in 1994) to accommodate two approaches: $\mathrm{CF}$ and sustainable forest management. Conserving and enhancing biodiversity through rural peoples' involvement was one of the components of the new forest policy act of 1995 (Sobze, 2003; Yufanyi Movuh, 2007: p. 1). This law lays emphasis on increasing the participation of the local populations in forest conservation and management in order to contribute to raising their living standards ${ }^{6}$. For the first time in Cameroon's history, the 1994 forest law and its 1995 decrees of application, provided for a legal instrument for community involvement in forest management (Yufanyi Movuh \& Krott, 2011; Oyono, 2005a, 2005b; Mandondo, 2003).

Although the implementation of CF differs in different countries $^{7}$, its concept and formulation goes far back to colonial times (Larson \& Ribot, 2007; Oyono, 2004b). Presently, it is being incentivised with development assistance in many, if not all of these formerly colonised countries, from a variety of different western or western-backed agencies and organisations, like the World Bank, KfW (German development bank) and GIZ for Cameroon ${ }^{8}$. After more than 14 years of CF implementation with financial support from international donors, the central government of Cameroon is gaining more control and influence of the forest resources than before, strengthening the top-down approach of forest policy implementation with strong tendencies towards re-centralization, dictated by the practices of bureaucrats and state representatives (Oyono, 2004b), contrary to the $\mathrm{CF}$ aim. This confirms the growing concerns that $\mathrm{CF}$ practice in many regions of the world is not attaining its intended objectives (Yufanyi Movuh \& Krott, 2011; Oyono,

\footnotetext{
${ }^{5}$ Although "Traditional Community Forestry" models have existed long in the local communities before the present introduced models by Western NGOs and agencies (Yufanyi Movuh \& Krott, 2011; Larson \& Ribot, 2007; Sunderlin, 2004: 3; Oyono, 2005b).

${ }^{6}$ The Forestry Law No 94/01 of 20th January 1994 and its decrees of application No 95/531/PM du 23 August 1995.

${ }^{7}$ Cameroon forestry law definition of community forestry: A community forest is "a forest forming part of the non-permanent forest estate, which is covered by a management agreement between a village community and the Forestry Administration. Management of such forest-which should not exceed 5000 ha - is the responsibility of the village community concerned, with the help or technical assistance of the Forestry Administration." Source: Article 3(11) of Decree 95/531/PM of 23 August 1995.

${ }^{8}$ GTZ (German technical service) and DED (German development service) have now merged with InWEnt, to be called GIZ (German Organisation for international cooperation).
} 
2004b). In Cameroon, CF has been proven to be a leverage for colonial legacy and entanglement (Yufanyi Movuh \& Krott, 2011) and an instrument of power against a backdrop of development assistance reminiscent to colonial times. Just like the 1974 land tenure law that followed the French colonial conception and which is still in place today in Cameroon ${ }^{9}$, the 1994 forestry law reinforced the colonial conception of the state as the ultimate owner of the national forest domain although it established for the first time in Cameroon the possibility for rural people to gain usufruct rights in the exploitation of forest resources in their neighbourhood.

Before, but especially since the inception of a different approach in forest policy in Cameroon through the new forestry law, European development agencies like GTZ, DED (now GIZ), KfW, AFD, (Agence Française de Développement), SNV, etc. have become more influential than ever in controlling the policies of natural resource management in Cameroon. They have become a sine qua non for the formulation and implementation of $\mathrm{CF}$ in tandem with their political ideologies of westernisation (Oyono et al., 2005: p. 364; Mbile et al., 2009; Oyono, 2009; Yufanyi Movuh \& Krott, 2011). Also, in the last 3 decades, we have experienced a wave of criticism of the uncritical acceptance of development in the form of post-modern critiques against western development schemas (Ahorro n.p.; Matthews, 2004, 2006). These criticisms have been literally boosted or elaborated by contemporary theories like the postcolonial and post-development theories.

This paper will proceed by analysing the CF stakeholders' power network in Cameroon using conceptualisation, theory and empirical data from the research collected from field work in Cameroon.

\section{Materials and Methods}

The $\mathrm{CFWG}^{10}$ definition of $\mathrm{CF}$, includes community based natural resource management through programs emphasizing biodiversity conservation and sustainable forest management involving the local communities. Here, the practice of Council forestry in Cameroon is included as part of the CF. Thirteen communities (see Figure 1, map) were explored in the South West Region (SWR) of Cameroon and the history, status and stakeholders of the CFs were analyzed ${ }^{11}$. Stakeholders here, refer to those who have interests in and the potential to influence the CF processes. We classify them into two main groups: state and non-state stakeholders. The main state stakeholders relevant for CF are the central Ministry for Forestry and Wild-

\footnotetext{
"In the colonial times, lands were considered "vacant" and without "master" and as such defined as state land.

${ }^{10}$ The Community Forestry Working Group (CFWG) in Germany, within the Chair for Forest and Nature Conservation Policy of the University in Goettingen.

${ }^{11}$ The statistical population of the CFs was drawn from the number of Community and Council forest applications received by the Ministry of Forestry and Wildlife (MINFOF) until 2009 in Yaoundé-Cameroon as a whole. This sums up to 451 Community forest and 28 Council Forest applications with a total of $479 \mathrm{CFs}$, spread out in all the ten Regions of Cameroon.

${ }^{12}$ MINFOF (national and Regional-SWR), GTZ, DED (now GIZ), KfW/GFA, WWF, WCS are all representing the main Program, PSMNR-SWR.

${ }^{13}$ Program for the Sustainable Management of Natural Resources in the South West Region.

${ }^{14}$ This was done through the snowball method. It is a typical way to analyse networks.
}

life (MINFOF) and the regional and local forest administrations. The non-state stakeholders include forest users, forest users' groups and their federations; donors, forest-based enterprises; environmental and user associations and political parties; university and research institutions; media and consultants. Such stakeholders may belong to local/regional, national and international levels, all of which may be of worth in CF processes. For Cameroon and for this study, our identified non-state stakeholders are: GTZ, DED (now GIZ), KfW/GFA, WWF, WCS ${ }^{12}$, the Common Initiative Groups (CIG) and Village Forest Management Committees (VFMC) of the different communities with community and council forests respectively.

Quantitative and qualitative interviews were carried out with $\mathrm{CF}$ managers and forestry officers and at times with members of the CIG and VFMC, responsible for the management of these forests; with representatives of MINFOF-SWR, KfW/ GFA representing the main Program (PSMNR-SWR) ${ }^{13}$, for the facilitation of the implementation of the forestry law, hence CF. Structured questionnaires were used with closed and openedended questions. More than seventy interviews were conducted and observations noted, in the course of the research that lasted three years. Documents like the logframe (logical framework) of the PSMNR-SWR, Management Plans (MP) and Technical Notes (NT) of the CFs were also part of the materials collected and analyzed.

The selections of the community and council forestry samples were done the map of the PSMNR-SWR (Figure 1) and based on information on recent activities of the communities in the CF process. It is also an area where the researcher has a good existing knowledge. From this population, a simple random selection was made. Interviews carried out with different stakeholders were in relation to the information given by other stakeholders in their networking (Schnell et al., 2005) and interest representation in $\mathrm{CF}^{14}$. All the interviews were recorded for transcription and further analyses. The quantitative network analysis uses the knowledge of the stakeholders to identify the partners of the network while the qualitative analysis goes deeper to describe and evaluate the powerful stakeholders, identified through the quantitative network analysis(see Schusser et al., 2012: p. 6). More the qualitative and less the quantitative analysis will be used to test our actor-centered power (ACP) and post-development theories through the concept and practice of $\mathrm{CF}$ in Cameroon.

In employing a critical realistic sequence of quantitative and qualitative research design approach, Schusser et al. (2012) identify stakeholders and their respective influence, providing explanations of activities and power in CF settings.

\section{Definitions and Theoretical Roots}

\section{Actor-Centered Power (ACP)}

Despite being the crucial question of political science, the concept of power played an increasingly minor role in the last decades' forest policy analysis. All the credit for the reintroduction of a power concept is due to Bas Arts and Jan van Tatenhove who published a conceptual framework on power in 2004 (Schusser, 2012: p. 2; Krott et al., in review). Although we think that powerful actors influence the policy outcomes heavily, we still need to understand the social phenomenon called "power" in the given context of forest policy issues. ${ }^{15}$ Many political scientists including Weber offered explanations and

${ }^{15}$ ibid. 
M. C. YUFANYI MOVUH, C. SCHUSSER

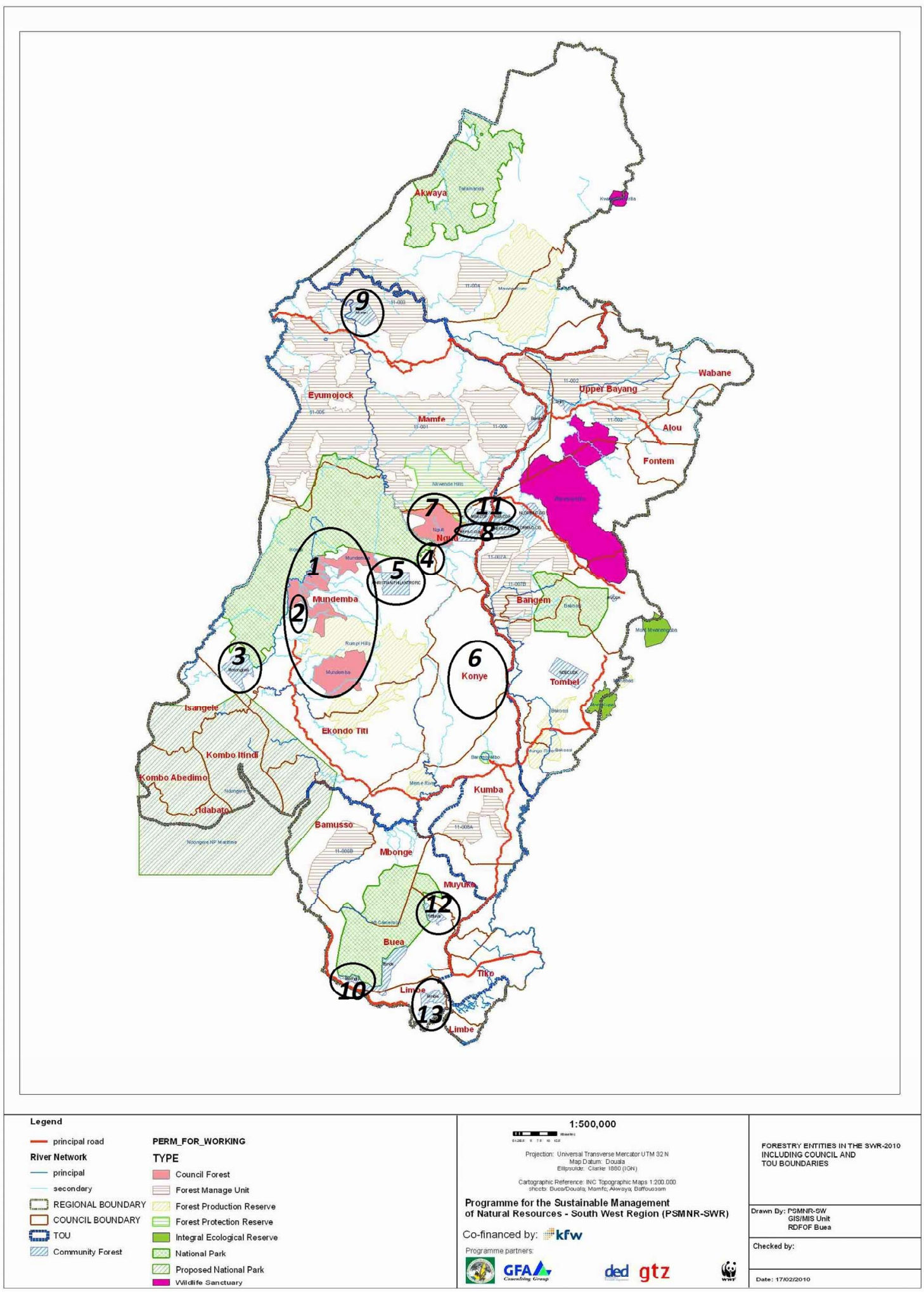

Source PSMNR 2010

Figure 1.

Community and Council Forestry regions in the PSMNR-SWR: Areas visited are encircled. 
definitions of power but there has been little reference directly linking forest policy analysis and development. To analyze power in forest policy analysis, we need to focus on single actors and their interaction in detail and therefore, the theory should focus on that substance of social behaviour.

This paper aims to analyze the empirically applicable concept of an ACP that consists of the following power sources (see Box 1): Trust, Incentives and Coercion and at the sametime connect these elements with the post-development theory. The elements were derived from basic assumptions on power made by Weber (1947) and Krott (1990). The elements are clearly defined and described with instruments and empirical findings. To analyze the social relations of forest policy actors in Cameroon, a simple concept that is strictly reduced to the basics of social interaction was suggested. For clarity's sake, in this text an actor exercising power is called A and an actor receiving power B. Our ACP concept defines power as follows:

Power is a social relationship, where an actor A alternates the behavior of actor $B$ without recognizing $B$ 's will.

For Weber (1947: p. 152), power is, "the probability that one actor within a social relationship will be in a position to carry out his own will despite resistance, regardless of the basis on which this probability rests". That is, the chance of a person or of a number of persons to realize their own will in a communal action even against the resistance of others who are participating in the action (Schusser, 2012: p. 2; Krott et al., in review).
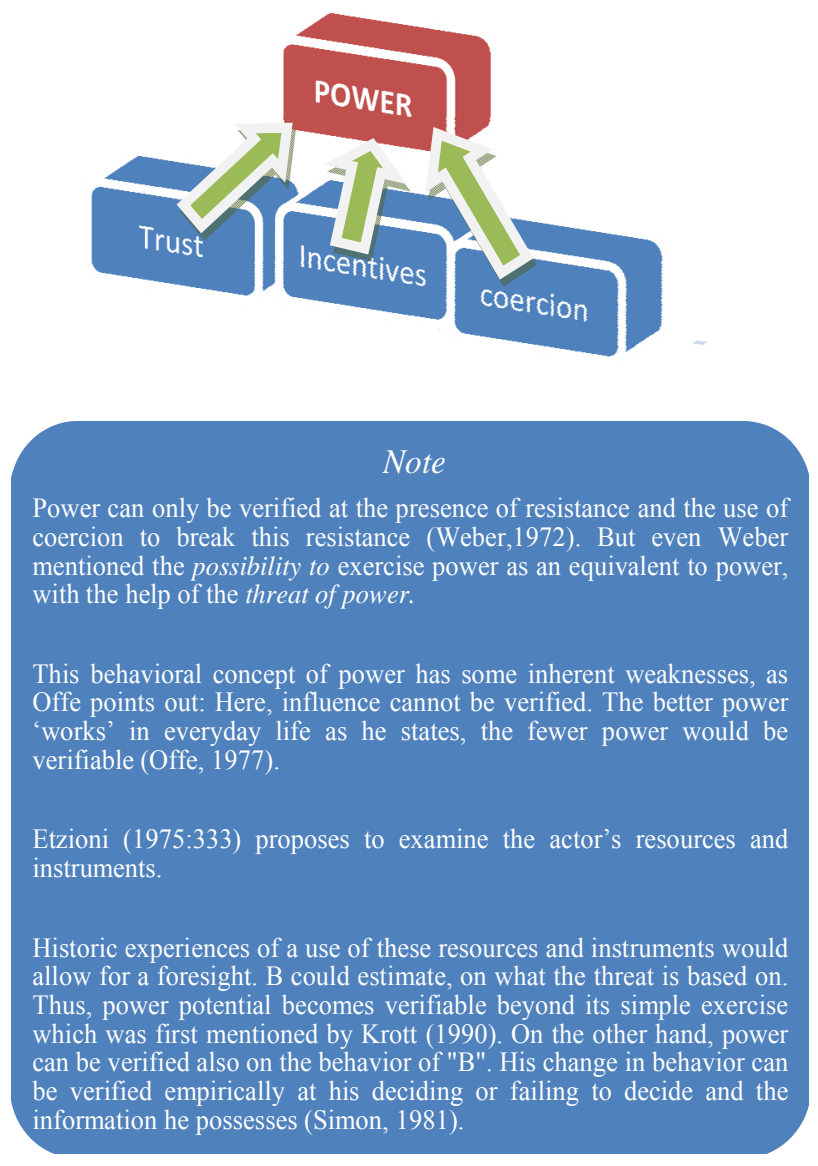

Box 1.

ACP concept consists of three elements: Trust, Incentives, and Coercion.
We define trust as a power element when one stakeholder B, changes behaviour by accepting for example, stakeholder A's information without check. A might typically achieve this situation by persuasion, prestige and reputation or by withholding information from B. Trust can be assumed through furnishing or provision of information, checks or a high frequency of interaction with a stakeholder. It is B's confidence to A's goodwill that makes B behave accordingly. It happens when $\mathrm{B}$ has the reasonable expectation that following the guidance of A will be beneficial.

The second element, incentives, are financial or non-financial factors that alters B's behaviour by motivation from A, ${ }^{16}$ which is most likely to be done by money, luxuries or any other kind of benefit. Here, transfers are likely to occur. In this case, it exists for B when B delegates to A control over good C in which B has an interest. To B, a behaviour according to A's incentives produces more benefits than a pursuit of A's former strategy to fulfil B's objectives. It is important to note, that B's inherent interests stay the same-just the behaviour changes. And this change was triggered by the benefits.

The third element, coercion, on the other hand is the practice of A forcing B to behave in an involuntary manner which can be done by violence or threat of violence. Coercion is force and control. If one cannot control other stakeholders, then there is a coercion problem or there is no coercion. Coercion can go with threat or action as a means of control. It is the application of pressure and that is why it is a top-down approach. As coercion builds resentment and resistance from $\mathrm{B}$, it tends to be the most obvious but least effective form of power because it demands a lot of control. When coercion comes to play, B can do little or nothing about it.

Although at times the complex theoretical analysis of the APC only generates face validity and lacks content validity (i.e., not being able to analyze a meaningful range of power) we are going to contentiously and empirically analyse it, pertaining to $\mathrm{CF}$ as a development tool in Cameroon.

In the last three decades, critical political and social scientists alike have grown interest in analysing the global society, especially areas of the world with weak economies that strive for better social and economic developments. They use critical theories to deconstruct the Development Theory that emerged in the period after World War II (late 1940s). These researchers and theorists have been interested in the role of development in poverty alleviation and stability, in the social systems where development has become the status quo and the notion of poverty alleviation obsolete. This interest has grown significantly since the early 1980s, from works of scholars like Sachs ed. (1992), Escobar (1995) and Rahnema \& Bawtree (1997), in the field of post-structuralism and post-development. This has been characterized by the continuing changes in the society, triggered by the unsatisfactory manifestation of the power relations between stakeholders of development. On the other hand, less has been invested in the role of power in the development and poverty alleviation process of the concerned societies. It is also the objective of this paper to use the post-development theory to explain this role.

\section{Post-Development Theory and the Policy Discourse}

Post-development theory argues that the whole concept of

\footnotetext{
${ }^{16}$ As far as technical support changes the behaviour of B (through motivation) it is part of a power process.
} 
development and practice is influence by Western-Northern hegemonies, with blueprints of their values over the rest of the world. Its theorists call for the rejection of the development concept (Rahnema \& Bawtree, 1997; Sachs Ed., 1992; Escobar, 1995), looking beyond it. It began during the 1980s following criticisms of development projects and the development theory justifying them (Matthews, 2004). It hitherto ostracises development as a tool used by western societies in the post-world war II era, to define development concerns, dominating the power relations arena, with the interests of the so-called development experts (the World Bank, IMF and other western development agencies) defining the development priorities, excluding the voices of the people they are supposed to develop, with intrinsically negative consequences. The post-development theory argue that to attempt to overcome this inequality and negative consequences, the stage should be taken over by non-western, non-northern peoples, to represent their priorities and concerns. It differs from other critical approaches to development (like dependency theory, alternative development theory and human development) in that it hitherto rejects development in its present form and calls for an alternative to development (Sachs ed., 1992; Escobar, 1995; Rahnema, 1997; Matthews, 2004, 2006), thus, moving beyond development.

Post-development theorists do not reject development ${ }^{17}$ per se but the development that has been a response to the problematization of poverty that occurred in the years following World War II (Klipper, 2010; Matthews, 2004), and label this type of development as being "an historical construct that provides a space in which poor countries are known, specified and intervened upon" (Escobar, 1995: p. 45). Hobley (2007: p. 4) rhetorically asks, "why, if this was so clearly the case thirty years ago, we are still repeating the same mistakes with the same consequences", echoing poverty alleviation also as being a rationale for the international funding of CF. Foucault described this as a form of power which, "makes individuals subjects; categorises the individual, marks him by his own individuality, attaches him to his own identity, imposes a law of truth on him which he must recognise and which others have to recognise in him" (Foucault, 1983: p. 212), with individual and collective effects. With its roots in post-modern critiques of modernity, one of the main arguments by theorists of postdevelopment against development practices is the well-established modernist powerful economic, socio-political and ecological interests in the pursuit of development. By deconstructing the development practice and theory, they reveal the operations of power and knowledge in development discourse and practices (Kippler, 2010: p. 2).

\section{Why the Analysis of ACP and Post-Development in CF}

Power, although being a core element of social and political sciences, has nevertheless played a less important role in forest policy (Krott et al., in review) and post-development theory analysis. It is understood from many scholars in the field of post-structuralism and post-development studies (Sachs, 1992; Rahnema \& Bawtree, 1997; Little \& Painter, 1995; Berger, 1995; Escobar, 1995; Crew \& Harrison, 1998; Pieterse, 1998; Blaike, 1998; Kiely, 1999; Storey, 2000; Babbington, 2000) that power is neglected in the post-developmentists' deconstruction of development. Escobar (2000) points out that it

\footnotetext{
${ }^{17}$ Development being an improvement or progress in life standards in time.
}

might even be suggested that post-development theorists do not understand power since power lies in the material and with the people, not in discourse, stressing livelihood and people's needs and not theoretical analyses to be of more importance. On the other hand, Rossi (2004: p. 2) argues that, "discourse is a form of power, producing reality, domains of objects and rituals of truth".

We argue that it is not the one or the other. We believe that using the power processes in our concept, we can easily decipher and confirm the arguments of the post-development theorists in analyzing our hypothesis that power is a hidden factor in development assistance. And because it is hidden and resists scientific analysis, it plays a major role (Offe, 1977; Krott, 2005: p. 14). Furthermore, we do not want to assume that the contact with development and the commodity is to be interpreted as a desire for development and the commodity on the part of those affected, arguing that such contacts are made possible through the enactment of a cultural politics by development advocates, in which development and the commodity are prioritized and bestowed upon the subaltern (Escobar, 2000). The only way to explain this is by analyzing the visible and invisible power processes behind these political enactments upon subaltern groups. They willingly or otherwise become actors of a cultural if not hegemonial politics bestowed on them as they struggle to defend their places, existence, ecologies, and cultures.

Until recently, only a few African scholars have had something to say about post-development theory although it goes without doubt that the critique of development offered by post-development theory is very important to Africa ${ }^{18}$. Relatively little attempt has been made to relate the post-development perspective to the continent (Matthews, 2004: p. 374). The fusion of theory with empirical case studies gives the possibility for a better understanding of both our ACP concept and the post-development theory, countering the criticism of post-development theory as being able to offer a critique of development but lacking instrumentality in relation to practice (Kippler, 2010), the same critique that is levied on many theories on power. As Matthews (2004: p. 377) explains further, even those few African scholars who have published work on development, have not taken into account the post-development perspective, be it from anything similar to a post-development perspective or discussions and literature focusing on the question of development in Africa. The present CF model in Cameroon is a practical example in natural resource management where powerful international actors propose, formulate, impose and implement forest policies through development aid or assistance. Larson and Ribot (2007: p. 190) point out that forest policy and the implementation-"systematically exclude various groups from forest benefits-and often impoverish and maintain the poverty of these groups". Eighteen years after the new forestry law in Cameroon was proclaimed, the present $\mathrm{CF}$ model is still to achieve its objective of sustainable forest management and poverty alleviation through the communities by acquiring benefits from $\mathrm{CF}$.

\section{Result}

\section{Evaluation of Power in Community Forestry}

In all thirteen CFs visited between 2009 and 2011, ten CFs

${ }^{18}$ it recognises the failure of the post-World War II (also post-colonial) development project which is illustrated by the African experience. 
had some form of regulated activities perceived to conform with the definition of our CFWG and also MINFOF classification as a CF. Table 1 shows the different cases of CF analysed, indicating the presence or not, of donor involvement in the form of development assistance to the GoC through MINFOF and the PSMNR-SWR to the CF.

\section{Empirical Finding-Resources}

Through our critical realistic sequence of quantitative and qualitative research design approach (Schusser et al., 2012), two stakeholder blocks were identified from the state and non-state groups as being the most influential. MINFOF [state] and the GDC, ${ }^{19}$ German Development Cooperation [non-state] were identified as being more powerful than others in all the cases studied, determining most of the outcomes of CF in the region. This is the reason why they are always mentioned in the empirical findings.

In 2004, a financial agreement (themed: German Financial Cooperation with Cameroon; Program for the Sustainable Management of Natural Resources in Cameroon South West Region) was signed between the GoC (represented by MINEFI-Ministry of Economy and Finance, MINFOF and the Autonomous Sinking Fund) and the government of the federal republic of Germany (represent by KfW, GTZ and DED). This financial agreement was a form of development aid from Germany to Cameroon to assist in the sustainable management of the natural resources of the SWR through the PSMNR-SWR and continues until date. In the same year, the sum of seven million EURO under the supervision of the Federal Ministry for Economic Cooperation and Development (BMZ), with document No.: 200465 252, was disbursed after a separate Agreement (by all actors concerned) to the financing Agreement dated December 29, 2004 was signed. Since then, the promotion and support of CF to enhance community participation was a main objective in the PSMNR, against the backdrop of sustainable forest management and poverty alleviation. Notwithstanding this flow of financial, technical and material assistance in $\mathrm{CF}$, results gathered from the field research show less progress in $\mathrm{CF}$ being an income generator for the local community who are custodians of the forest.

$\mathrm{CF}$, which was supposed to be a form of decentralization of forest resource management and a form of devolution of power to the local communities has instead strengthen the grip of central MINFOF over the communities with CF. Furthermore, the dependency of the GoC (MINFOF) on financial assistance from Germany and other western countries to run the PSMNR has also increased the influence of these actors over policy and implementation of CF. Without these funds, activities in CF will be almost impossible since certain technical documents and related services have to be paid for by communities who are themselves financially not viable. Empirically, the three elements of power are used to confirm the existence and strong influence of powerful international actors in CF. These elements also confirm the arguments of the post-development theorists, that development, in this case through CF in Cameroon should be rejected since it is a project premised upon a set of values that are not found or regarded strange in the society in which it is implemented and in the long run cannot succeed and will be reason for its demise.

\section{The Power Element Trust}

Trust as defined in the ACP concept is where an actor B complies without a check of information given by another actor A. As Fisher et al. (2010) put it, trust arises from a judgement of whether to place oneself in a position of potential vulnerability by granting others discretionary power over one's interests. At a certain stage, A is trustworthy just to the extent that he attends to B's interests, values, and collective identities. Seen from B's point of view, trust suspends the need of control over A (Möllerring, 2005: p. 299).

$\mathrm{CF}$ in Cameroon came with the objective of enhanced participation of the communities concerned in managing their forest resources sustainably and at the same time benefit financially from it, hence, attaining a progressive development. But in most cases that concerns trust in the powerful actors that govern CF (be it to MINFOF or international organisations), a thorough check by the local stakeholders concerned is just too complex, time-consuming and expensive and therefore inefficient for them, so they rely on the unchecked information given to them by the powerful actors.

In all the case studies mentioned in Table 1, it was observed that trust was granted to MINFOF and the international organisations representing the GDC. While the local actors like the CIGs and VFMCs trust MINFOF and the other government ministries concerned with $\mathrm{CF}$, when they comply without any check of alternatives, MINFOF also trusts the GDC by accepting the conditions in the way the PSMNR is going to be managed, also without any check of alternatives. It could be observed in the field that staff of the GDC were very much trusted by the MINFOF staff without check of Information. It could also be observed that the CIGs, VFMCs and MINFOF respectively do not check or are not able to check information from the GDC but use it as a basis for orientation. If they would have the means to check or double-check the information and would hence be able to agree to it voluntarily, there would no power process because here, both parties would have the same interests, but this is not the case.

Also, in the past, the GDC has always been supporting as a development goal, the green sector in Cameroon and this is also a reason for trust without checks. In the above mentioned 2004 separate (bilateral) contract between the German Cooperation and the $\mathrm{GoC}$, the GoC accepted the GFA/DFS ${ }^{20}$, (a decision from KfW) without checking, as the main consultancy partner to manage the PSMNR-SWR with MINFOF. Here, the acceptance of MINFOF could be interpreted as change of behaviour due to motivations from the GDC but this could not be confirmed in the research. Officially, the GFA and DFS were selected as program consultants (supposedly through an international bidding process) to assist the program implementation agency, MINFOF, in the coordination of the PSMNR-SWR. However unofficially, they act as a watchdog to MINFOF and monitor the interests of the KfW (personal interview with some PSMNR staff). This again shows that while MINFOF trusts the German partners, it is not reciprocal or mutual, tilting the power element more to the GDC. Nevertheless, there is a fine line between trust to a specific actor and change of behaviour due to motivations initiated by that same actor. This is categorized under incentives.

\section{The Power Element Incentives}

In an actor-centered perspective, it is the expectation of ${ }^{19}(\mathrm{GIZ}, \mathrm{GFA} / \mathrm{KfW})$
${ }^{20} \mathrm{GFA}$ is an international consultancy firm based in Hamburg, Germany/
DFS-Deutsche Forstservice GmbH. 
Table 1.

General information of the selected community forests (CFs) in the SWR of Cameroon.

\begin{tabular}{|c|c|c|c|c|c|c|}
\hline & Communit(y)ies & Forest status & Name of management institution & $\begin{array}{l}\text { Resource } \\
\text { status }\end{array}$ & $\begin{array}{c}\text { Donor } \\
\text { involvement }\end{array}$ & Visited \\
\hline 1 & Mundemba & Council forest, Reserved & Mundemba rural council (Ndian) & Rich & Yes, GIZ (GTZ) & $2009 / 2011$ \\
\hline 2 & Ikondo Kondo & $\begin{array}{l}\text { Community forest (not } \\
\text { exsting anymore) }\end{array}$ & Mundemba rural council (Ndian) & Rich & $\begin{array}{l}\text { Not anymore but } \\
\text { previously GTZ }\end{array}$ & $2009 / 2011$ \\
\hline 3 & Mosongiseli & $\begin{array}{l}\text { Community forest, } \\
\text { Reserved }\end{array}$ & $\begin{array}{l}\text { Mosongiseli Balondo Badiko CIG } \\
\text { (MBABCIG) (Ndian) }\end{array}$ & Rich & Yes, GIZ (DED) & $2009 / 2011$ \\
\hline 4 & Toko & $\begin{array}{c}\text { Council forest, (not exsting } \\
\text { anymore) }\end{array}$ & Toko rural council (Ndian) & Poor & $\begin{array}{l}\text { Not anymore but } \\
\text { previously GTZ }\end{array}$ & $2009 / 2011$ \\
\hline 5 & Itali & Community forest & $\begin{array}{l}\text { Christian philanthropic Farms and } \\
\text { Missions (CPFAM) CIG (Ndian) }\end{array}$ & $\begin{array}{l}\text { Rich but no } \\
\text { access }\end{array}$ & No & $2009 / 2011$ \\
\hline 6 & Konye & $\begin{array}{c}\text { Council forest, (not exsting } \\
\text { anymore) }\end{array}$ & Konye rural Council (Meme) & Poor & $\begin{array}{l}\text { Not anymore but } \\
\text { previously GTZ }\end{array}$ & $2009 / 2011$ \\
\hline 7 & Nguti & Council forest, Reserved & $\begin{array}{l}\text { Nguti rural council } \\
\text { (Kupe-Muanengouba) }\end{array}$ & Rich & Yes, GIZ (DED) & $2009 / 2011$ \\
\hline 8 & Manyemen & $\begin{array}{l}\text { Community forest, } \\
\text { Operational }\end{array}$ & REPA-CIG (Kupe-Muanengouba) & Rich & $\begin{array}{l}\text { Not anymore, but } \\
\text { previously CA- } \\
\text { FECO }\end{array}$ & $2009 / 2011$ \\
\hline 9 & Akwen & Community forest & Akwen CF (Manyu) & Rich & Yes, GIZ (DED) & $2009 / 2011$ \\
\hline 10 & Bakingili & $\begin{array}{l}\text { Community forest, } \\
\text { Reserved }\end{array}$ & $\begin{array}{l}\text { Bakingili CF management CIG } \\
\text { (Fako) }\end{array}$ & Poor & Yes, GIZ (DED) & $2009 / 2011$ \\
\hline 11 & MBACOF & $\begin{array}{l}\text { Community forest, } \\
\text { Reserved }\end{array}$ & $\begin{array}{l}\text { MBAAH community forest CIG } \\
\text { (Kupe-Muanengouba) }\end{array}$ & nd & No & 2011 \\
\hline 12 & Woteva Village & $\begin{array}{l}\text { Community forest, } \\
\text { Reserved }\end{array}$ & $\begin{array}{c}\text { Woteva village development CIG } \\
\text { (WODCIG) (Fako) }\end{array}$ & nd & Yes, GIZ (DED) & 2011 \\
\hline 13 & Bimbia-Bonadikombo & $\begin{array}{l}\text { Community forest, } \\
\text { Operational }\end{array}$ & CF management CIG (Fako) & Poor & $\begin{array}{l}\text { Not anymore but } \\
\text { previously MCP }\end{array}$ & $2009 / 2011$ \\
\hline
\end{tabular}

Source: From Author (nd = no data).

benefits that encourages actor B to change behaviour through motivation from actor A.

Due to incentives from international organisations and agencies like the Bretton Woods institution, World bank, and KfW, the $\mathrm{GoC}$ was encouraged or otherwise motivated to make changes in its forest policy to suit the goal of these institutions and the 1994 Forestry Law No. 94/01 of 20th January 1994 and its decrees of application No. 95/531/PM of 23 August 1995 were some of the outcomes of this changed behaviour (Mbile et al., 2009; Yufanyi Movuh \& Krott, 2011; Bigombé, 2003; Oyono, 2005a: p. 318). Also, the seven million EURO budget made available to the $\mathrm{GoC}$ as development assistance for the first phase (2006-2010) of the PSMNR-SWR was identified as motivation or incentive enough to change the behaviour of its ministries like MINFOF.
On the other hand, a very good field example is the case of the Community of Ikondo Kondo in the Mundemba municipality. They were resettled from the Korup National Park and promised a CF by the authorities that be. As years went by and although they still had the interest of acquiring a CF which they could manage by themselves, they were lured or otherwise motivated to join the Mundemba CF instead. Here it should also be mentioned that there is also a form of negative incentives (disincentives) at play in this case. They accepted to change their behaviour, in accordance with the offer of MINFOF, GTZ and DED, else they would have lost everything that would have given them future benefits. Their estimation was that the price they will have to pay for their resistance may be higher than their chance of obtaining a positive outcome, or than the benefit they may gain (Sadan, 1997: p. 48). The Ikondo 
Kondo case shows that although the chief of the community (who works with MINFOF) was well informed about CF and tried to follow up the process for almost ten years, facing a strong incentive (disincentive) structure like MINFOF and the GDC, the Community was driven towards the goals of the present day GIZ.

Motivation in form of financial or non-financial incentives (technical and material) or de-motivation in the form of loss, by MINFOF or the GDC was observed in all the field studies performed. 100 per cent of the cases displayed disincentives in form of fear of losing the communal land (e.g. Ikondo Kondo, Mosongiseli, Bakingili, Woteva, Akwen) to GoC, which would then be used for other natural resource management (NRM) purposes. Sometimes it might not be easy to distinguish between disincentive and threat, which we categorized under coercion

\section{The Power Element Coercion}

In an actor centered perspective, coercion is the practice of forcing actor B to behave in an involuntary manner which can be done by threat of violence or violence from $\mathrm{A}$.

In the case of $\mathrm{CF}$ in Cameroon, the pre-requisite of a forest inventory and a management plan for the gazettment of $\mathrm{CF}$ from MINFOF is a sort of control which can be linked to coercion; other stakeholders have to follow them. Some coercive power features for $\mathrm{CF}$ are that only MINFOF can decide which CIG or VFMC has fulfilled all the conditions for the gazettment of a particular CF. It also has the physical ability to keep other stakeholders out of the CF management process by using administrative and implementation limitations, such as signing of legal documents, monopoly of control of the whole CF process, with information and interpretation of legal issues. It also controls the administrative procedures required in the process (consultation meetings, forest inventory, boundary demarcation, management plan, management conventions, annual cutting area, quantity and quality of exploitation (in $\mathrm{m}^{3}$ and minimum diameters, respectively), carrying out actions that other stakeholders or actors cannot stop. There are other tenural characteristics and territorial restrictions (the state is the owner of the land) like e.g.: no CF can exceed 5000 ha and CF being just a landlease (for 25 years) issue and bi-product of protected areas and national parks policies, although with Council Forests, a different procedure holds.

The coercive power is crowned with the fact that MINFOF staff are also part of the armed forces in Cameroon. MINFOF has its own armed officers and where possible, they could be supported by the police, the para-military or the military officers (in patrols in the forest or on missions).

Empirically, there is a fine line when analysing disincentives and the threat of force e.g.: the threat of losing your CF to another community if there is no joint management with another community to manage the $\mathrm{CF}$ which was previously yours is at the same time an incentive (a disincentive) knowing that if a community does not accept the offer, MINFOF will go ahead and recognise only the other community as the legal custodian for the CF (Ikondo Kondo and Akwen CFs).

Important to note is the fact that the state through MINFOF has the overall control of definition and decision making in the process of establishing and management of CFs, while international organisations like GDC and the World Bank use incentives on the one hand and pressure on the other hand, to influ- ence forest policies of the GoC, especially with regard to $\mathrm{CF}$ in the name of development. Quoting Mbile et al. (2009: p. 3), "by the mid 1980s, the world economy was in decline, as was Cameroon's and under pressure from the Bretton Woods institutions of the World Bank, the GoC introduced a Structural Adjustment Program (SAP) in 1988 to reduce its debts and to lay the ground for the recovery. From 1988 to 2005, the policy landscape of Cameroon took on a new direction impacting in important ways on forest livelihoods". Mandondo (2003: p. 9) pointed out that 1994 forest law was, to a significant extent, imposed on the $\mathrm{GoC}$ as a condition for financial support under structural reforms funded by the Bretton Woods institutions, particularly the World Bank. Although there was some resistance from some politicians, this was overridden by a compliant so-called executive branch of the GoC.

\section{Conclusion}

\section{Power and Development}

Forest policy throughout Africa originates from European scientific forestry traditions exported during the colonial period (Larson \& Ribot, 2007; Yufanyi Movuh \& Krott, 2011). The natural resource policy in Cameroon is as old as Cameroon itself, but before the arrival of the first colonial administrators in the late 19th century, natural resources were managed according to the people's law or customary law; the village chiefs were the main administrators of resource management (Mengang Mewondo, 1998; Bigombé, 2003). In the past decades, Cameroon's rainforests and its conservation for global posterity has attracted much concern among northern "Green" NGOs like WWF, WCS, the international scientific community, the World Bank and bilateral aid agencies like SNV, DFID, GIZ or GDC (just to name a few), and other institutions with an interest in biodiversity conservation and sustainable development. These Organisations and institutions have inherited a rich heritage of colonial expertise and policies which they continue to implement till date. This could be confirmed also by the researcher.

Apparently, numerous efforts at rain-forest conservation in Cameroon and elsewhere in Africa, by western development aid agencies and NGOs alike are being made so as to link them with benefits to the rural poor, the custodians of the majority of these forest areas. Today's, protected areas are being created with the rationale of conservation or premise of mitigating unsustainable management of forest resources or unsustainable farm practices. The question here is if this is what will lead to sustainability and reduction in poverty. Moreover, the 1994 Forestry law is being implemented in a way which is not benefiting the local communities. The current forestry policies and the ways they are selectively implemented continue to reproduce the double standards and conditions that disadvantage, create and maintain the rural poor (Larson \& Ribot, 2007: p. 190). Can a law to foster sustainable forest management, devolution of forest resource management to local communities and conservation, externally defined and executed in project modes, be linked to communal approaches? Poverty alleviation, livelihood enhancement and economic development; all issues attracting contemporary donor funding were components or objectives of the present CF model accrued in the law and at the same time linked to conservation objectives ${ }^{21}$. One might argue

\footnotetext{
${ }^{21}$ The concept of post-development theories can also be used to analyse the intention behind such policies.
} 
that communities draw economic benefit from the $\mathrm{CF}$, but the state retains de jure ultimate control over the forests and the land on which they grow (Egbe, 1998). For us, the question is also, who are those who benefit economically. Is it the state, the international organisations, the external and internal elites or the rural forest user? Is it the chief and his henchmen who are compliant to the state or the local individual who lives from that forest? The answer through this study is definitely, not positive for the local forest user.

Today's forest policy in Cameroon is still shaped by colonial tradition and dominated by a scientific-cum-bureaucratic paradigm which is deterministic, reductionist, authoritarian and coercive (Murphree, 2004) and bears blueprint of decades of declared colonial heritage, upholding to the underlying concept or principle of colonial land tenure. There are still unresolved land tenure contestations in Cameroon and tenure issues have increasingly stifled the present CF model in achieving its objectives. Although the Cameroon Land Ordinance No. 74-1 of July 6, 1974 maintains that the State is the guardian of all lands, traditional authorities continue to exercise de facto rights over land. The resurgence of unresolved historical claims over boundaries and land including the natural resources which are embedded in them has been a stumbling block for CF (e.g.: Itali -CPFAM, Akwen, Ikondo Kondo). The uncertain and colonial-like land tenure situation makes the local stakeholders unable to fully embrace participatory forestry. Also, the colonial logic of resource accumulation, including building financial capital on forest exploitation (Oyono, 2005b: p. 124), has been replicated, with some modifications by the Cameroonian post-colonial state and propagated by the development aid agencies. This could also be confirmed in all the case studies.

The main message here is that the $\mathrm{GoC}$, with financial and technical support from their development cooperation stakeholders like GIZ and KfW, is using their decentralization propaganda to re-centralize power in the forestry sector; i.e., recentralization through decentralization (Ferguson, 1994: 180; Rossi, 2004: p. 3; Devkota, 2010: p. 78). Because the power exerted by the western hegemonies is less visible, it is stronger. The aim at this stage is not to totally reject CF but the present model has failed to produce benefits that can be equated to development after eighteen years. Hence, this model should be reconsidered by policy makers, to suit the needs and demands of the communities concerned. All the areas visited in the research displayed rich natural forests but the adjacent communities tend to have high poverty rates. These communities are dependent on their forest resources for a portion of their livelihood and none could boost of poverty alleviation through $\mathrm{CF}$ or even after acquiring a CF. Instead, they have fallen under the control of the state and its development partners. This study, is to empower these important but marginalised communities, and to improve policies and institutions (Mayers, 2005) in the forestry sector.

From our concept of the ACP, this study has proven that in Cameroon, the state and its international agents use the three elements of power described above to influence and defend their interests in CF. In the study, it was found that at a given situation, all three elements could overlap each other while distinctive processes could be used to analyse each power source separately. Furthermore, testing the post-development theory, it could also be proven that $\mathrm{CF}$, as a development instrument to alleviate poverty and improve livelihood while sustainably managing the forest has actually not brought sig- nificant or meaningful development to the targeted sector of the society.

Millions of Euro or billions of FCFA from international donors (with strings attached to them) have been used to steer the popularity and subsequent tradeoffs for programs promoting community participation, especially in CF. Through documents like forest inventories, management plans and conventions between the State and the communities, they keep the communities abbey, exercising far more authority than even before the implementation of the Forestry Law of 1994. With the present CF model, the influence and power of MINFOF and their international collaborators go up, while the power of the communities to control their forest activities is reduced. Thus, the different village committees (CIGs or VFMCs), lacking effective power and sometimes totally cut off from local communities they represent, have become captive to motivations other than the good of the community or the individual forest user.

\section{Acknowledgements}

This research was partly funded by the German Research Foundation (Deutsche Forschungsgemeinschaft/DFG) and GeorgAugust-University Goettingen.

\section{REFERENCES}

Agrawal, A., \& Redford, K. H. (2006). Poverty, development, and biondiversity conservation: Shooting in the dark? Working paper No. 26. New York: Wildlife Conservation Society.

Ahorro, J. (2008). The waves of post-development theory and a consideration of the Philippines. Edmonton: University of Alberta.

Arts, B., \& Van Tatenhove, J. (2004). Policy and power: A conceptual framework between the "old" and "new" policy idioms. Policy sciences, 37, 339-356. doi:10.1007/s11077-005-0156-9

Babbington, A. (2000). Re-encountering development: Livelihood transitions and place transformations in the Andes. Annals of the Association of American Geographers, 90, 495-520. doi:10.1111/0004-5608.00206

Barry, D., Campbell, J. Y., Fahn, J., Mallee, H., \& Pradhan, U. (2003). Achieving significant impact at scale: Reflections on the challenge for global community forestry. URL (last checked 19-23 May 2003). http://www.cifor.org/publications/corporate/cd-roms/bonn-proc/pdfs/ papers/t7_final_barry.pdf

Berger, M. (1995). Post-cold war capitalism: Modernization and modes of resistance after the fall. Third World Quarterly, 16, 717728. doi: $10.1080 / 01436599550035924$

Bigombe', P. (2003). The decentralized forestry taxation system in Cameroon. In J. Ribot, \& D. Conyers (Eds.), Local management and state's logic. Washington: World Resources Institute.

Blaike, P. (1998). Post-modernism and the calling out of development geography. Annual Meeting of the American Association of Geographers, Boston, 25-28 March 1998.

Brown, H. C. P., Wolf, S. A., \& Lassoie, J. P. (2007). An analytic approach to structuring co-management of community forests in Cameroon, Progress in Development Studies, 7, 135-154. doi:10.1177/146499340600700204

Colfer, C. J. P. (2005). The equitable forest: Diversity, community and resource management. Washington: RFF Press.

Contreras, A. (2003). Creating space for local forest management-The case of the Philippines. In D. Edmunds, \& E. Wollenberg (Eds.), Local forest management: The impacts of devolution policies (pp. 127-149). London: Earthscan.

Crew, E., \& Harrison, E. (1998). Whose development? An ethnography of aid. London: Zed Books.

Devkota, R. (2010). Interests and powers as drivers of community forestry: A case study of Nepal. Göttingen: University Press Göttingen. 
Edmunds, D., \& Wollenberg, E. (2001). Historical perspectives on forest policy change in Asia: An introduction, Environmental History, 6, 190-212. doi:10.1093/envhis/6.2.190

Egbe, E. S. (1998). The range of possibilities for community forestry permitted within the framework of current Cameroonian legislation. Yaoundé: Ministry of Environment and Forests.

Escobar, A. (1995). Encountering development. Princeton: Princeton University Press.

Escobar, A. (2000). Beyond the search for a paradigm? post-development and beyond, Development, 43, 11-14. doi:10.1057/palgrave.development. 1110188

Etzioni, A. (1975). A comparative analysis of complex organizations: On power, involvement, and their correlates. New York: Free Press.

Ezzine de Blas, D., Ruiz Perez, M., Sayer, J. A., Lescuyer, G., Nasi, R., \& Karsenty, A. (2009). External influences on and conditions for community logging management in Cameroon. World Development, 37, 445-456. doi:10.1016/j.worlddev.2008.03.011

Ferguson, J. (1994). The anti-politics machine: "Development", depoliticization, and bureaucratic power in Lesotho. The Ecologist, 24, 176-181.

Fisher, J., van Heerde, J., \& Tucker, A. (2010). Does one trust judgement fit all? Linking theory and empirics. British Journal of Politics \& International Relations, 12, 161-188. doi:10.1111/j.1467-856X.2009.00401.x

Foucault, M. (1983). The subject and power. In H. Dreyfus, \& P. Rabinow (Eds.), Beyond structuralism and hermeneutics. Chicago: The University of Chicago Press.

Hobley, M. (2007). Forests-The poor man's overcoat: Foresters as agents of change? Canberra: The Fenner School of Environment and Society, The Australian National University.

Kiely, R. (1999). The last refuge of the noble savage? A critical assessment of post-development theory. The European Journal of Development Research, 11, 30-55. doi:10.1080/09578819908426726

Kippler, C. (2010). Exploring post-development: Politics, the state and emancipation. The question of alternatives. URL(last checked 21 September 2011).

http://www.polis.leeds.ac.uk/assets/files/students/student-journal/ugsummer-10/caroline-kippler-summer-10.pdf

Krott, M. (1990). Öffentliche verwaltung im umweltschutz, ergebnisse einer behörden-orientierten policy-analyse am beispiel waldschutz. Wien: Braunmüller.

Krott, M. (2005). Forest policy analysis. Dordrecht: Springer.

Krott, M., Bader, A., Devkota, R., Schusser, C., Maryudi, A., \& Aurenhammer, A. (in review). Identifying driving forces in land use issues by actor-centered power analysis-Example of community forestry. In Review in Land Use Policy.

Larson, A. M. (2005). Democratic decentralization in the forestry sector: Lessons learned from Africa, Asia and Latin America. In C. J. Colfer, \& D. Capistrano (Eds.), The Politics of decentralization-Forests, power and people (pp. 32-62). London: Earthscan.

Larson, A. M., \& Ribot, J. C. (2004). Democratic decentralization through a natural resource lens. European Journal of Development Research, 16, 1-25.

Larson, A. M., \& Ribot, J. C. (2007). The poverty of forestry policy: Double standards on an uneven playing field. Sustainability Science Journal, 2, 189-204.

La Viña, A. G. M. (1997). Seeing with clear eyes: The challenge of community-based resource management and the role of academe. In C. Castro, F. B. Pulhin, \& L. C. Reyes (Eds.), Community-based resource management: A paradigm shift in forestry. Los Baños: University of the Philippines Los Baños.

Little, P., \& Painter, M. (1995). Discourse, politics, and the development process: Reflections on Escobar's “anthropology and the development encounter”. American Ethnologist, 22, 602-616. doi:10.1525/ae.1995.22.3.02a00080

Mandondo, A. (2003). Snapshot views of international community forestry networks: Cameroon country study. Center for International Forestry Research.

Maryudi, A. (2011). The contesting aspirations in the forests: Actors, interests and power in community forestry in Java, Indonesia.
Göttingen: University Press Göttingen.

Maryudi, A., Devkota, R., Schusser, C., Yufanyi Movuh, M., Salla, M., Aurenhammer, H., \& Krott, M. (2012). Back to basics: Considerations in evaluating the outcomes of community forestry. Forest policy an Economics, 14, 1-5.

Matthews, S. (2004). Post-development theory and the question of alternatives: A view from Africa. Third World Quarterly, 25, 373384. doi: $10.1080 / 0143659042000174860$

Matthews, S. (2006). Responding to poverty in the light of the post-development debate: Some insights from the NGO Enda Graf Sahel. Africa development, 4, 52-72.

Mayers, J. (2005). Stakeholder power analysis. London: International Institute for Environment and Development (IIED).

Mbile, P., Ndzomo-Abanda, G., Essoumba, H., \& Misouma, A. (2009). Alternate tenure and enterprise models in Cameroon: Community forests in the context of community rights and forest landscapes. Washington: World Agro forestry Centre and Rights and Resources Initiative.

McDermott, M. H., \& Schreckenberg, K. (2009). Equity in community forestry: Insights from north and south. International Forestry Review, 11, 157-170. doi:10.1505/ifor.11.2.157

Mengang J. M. (1998). Resource use in the tri-national Sangha river region of equatorial Africa: Histories, knowledge forms, and institutions. Bulletin, 102, 8-28

MINEP (2004). Etat des lieux de la foresterie communautaire au Cameroun. Ministere de 1'Environnement et des Forets, Direction des Forêts, Cellule de Foresterie Communautaire.

Möllering, G. (2005). The trust/control duality: An integrative perspective on positive expectations of others. International Sociology, 20, 283-305. doi:10.1177/0268580905055478

Murphree, M. (2004). Communal approaches to natural resource management in Africa: From whence and to where? Berkeley: Center for African Studies.

Offe, C. (1977). Einleitung. In P. Bachrach, \& M. Baratz (Eds.), Macht und Armut: Eine theoretisch-empirische Untersuchung (pp. 7-34). Frankfurt: Verlag.

Oyono, P. R. (2004a). Institutional deficit, representation, and decentralized forest management in Cameroon. Washington: Elements of natural resource sociology for social theory and public policy, Environmental Governance in Africa.

Oyono, P. R. (2004b). One step forward, two steps back? Paradoxes of natural resource management decentralization in Cameroon. Journal of Modern African Studies, 42, 91-111. doi:10.1017/S0022278X03004488

Oyono, P. R. (2005a). Profiling local-level outcomes of environmental decentralizations: The case of Cameroon's forests in the Congo Basin. Journal of Environment and Development, 14, 317-337.

Oyono, P. R. (2005b). The foundations of the conflit de langage over land and forests in southern Cameroon. African Study Monographs, 26, 115-144.

Oyono, P. R. (2009). New niches of community rights to forests in Cameroon: Tenure reform, decentralization category or something else? International Journal of Social Forestry, 2, 1-23.

Oyono, P. R., Kouna, C., \& Mala, W. (2005). Benefits of forests in Cameroon: Global structure, issues involving access, and decisionmaking hiccoughs. Forest Policy and Economics, 7, 357-368. doi:10.1016/S1389-9341(03)00072-8

Pieterse, J. N. (1998). My paradigm of yours? Alternative development, post-development, and reflexive development. Development and Change, 29, 343-373. doi:10.1111/1467-7660.00081

Poffenberger, M. (2006). People in the forest: Community forestry experiences from southeast Asia. International Journal of Environment and Sustainable Development, 5, 57-69.

Pulhin, J. M., \& Dressler, W. H. (2009). People, power and timber: The politics of community-Based forest management. Journal of Environmental Management, 91, 206-214. doi:10.1016/j.jenvman.2009.08.007

Rahnema, M. (1997). Development and the people's immune system: The story of another variety of AIDS. In M. Rahnema, \& V. Bawtree, (Eds.), The post-development reader (pp. 111-129). London: Zed 


\section{C. YUFANYI MOVUH, C. SCHUSSER}

Books.

Rahnema, M., \& Bawtree, V. (Eds.) (1997). The post-development reader. London: Zed Books.

Rebugio, L. L. (1998). Paradigm shift: The key to sustainable forestry and environmental resources management. Asian Journal of Sustainable Agriculture, 1, 13-24.

Rossi, D. (2004). Revisiting foucauldian approaches: Power dynamics in development projects. Journal of Development Studies, 40, 1-29. doi: $10.1080 / 0022038042000233786$

Sachs, W. (Eds.) (1992). The development dictionary. A guide to knowledge as power. London: Zed Books.

Sadan, E. (1997). Empowerment and community planning: Theory and practice of people-focused social solutions. Tel Aviv: Hakibbutz Hameuchad.

Sarin, M., Singh, N., Sundar, N., \& Bhogal, R. (2003). Devolution as a threat to democratic decision-making in forestry? Findings from three states in India. in D. Edmunds, \& E. Wollenberg (Eds.), Local forest management: The impacts of devolution policies (pp. 55-126). London: Earthscan.

Schnell, R., Hill, P., \& Esser, E. (2005). Methoden der empirischen Sozialforschung. München: Auflage.

Schusser, C. (2012). Who determines biodiversity? An analysis of actors' power and interests in community forestry in Namibia. Forest Policy and Economics, 21 July 2012.

Schusser, C., Krott, M., Devkota, R., Maryudi, A., Salla, M., \& Yufanyi Movuh, M. C. (2012). Sequence design of quantitative and qualitative surveys for increasing efficiency in forest policy research. Allgemeine Forest und Jagdzeitung, 183, 75-83.

Shackleton, S., Campbell, B., Wollenberg, E., \& Edmunds, D. (2002). Devolution and community-based natural resource management: Creating space for local people to participate and benefit? Natural Resource Perspectives, 76, 1-6.

Sikor, T. (2006). Analyzing community-based forestry: Local, political and agrarian perspectives. Forest Policy and Economics, 8, 339-349 doi:10.1016/j.forpol.2005.08.005

Simon, H. A. (1981). Entscheidungsverhalten in organisationen: Eine Untersuchung von entscheidungsprozessen in management und verwaltung. Landsberg am Lech.

Sobze, J. M. (2003). Analysis of implication of forest policy reform on CF in Cameroon: Case study of Lomié. Göttingen: Cuvillier Verlag.

Storey, A. (2000). Post-development theory: Romanticism and pontius pilate politics. Development, 43, 4.

Sunderlin, D. W. (2004). Community forestry and poverty alleviation in Cambodia, Lao-PDR, and Vietnam: An agenda for research. Jakarta: Center for International Forestry Research.

Thoms, C. A. (2006). Conservation success, livelihoods failure? Community forestry in Nepal. Policy Matters, 14, 169-179.

Weber, M. (1964). The theory of social and economic organization. New York: Oxford University Press.

World Bank (2004). Sustaining forests: A development strategy. Washington: The World Bank.

World Bank (2005). World development indicators 2005. Washington: World Bank.

World Resources Institute (2005). The wealth of the poor-managing ecosystems to fight poverty. Washington: United Nations Development Program, United Nations Environment Program, World Bank, World Resources Institute.

Yufanyi Movuh, M. C. (2007). Community-based biodiversity conservation management: Reaching the goal of biodiversity conservation and community development. Master's Thesis, München: GRIN Publishing.

Yufanyi Movuh, M. C., \& Krott, M. (2012). The colonial heritage and post-colonial influence, entanglements and implications of the concept of community forestry by the example of Cameroon. Forest Policy and Economics, 15, 70-77. doi:10.1016/j.forpol.2011.05.004 